\title{
Richard Aldington's Images, the Metropolis and the Masses
}

\section{Andrew Frayn}

De Montfort University

Richard Aldington's city poems in the latter part of his 1915 collection Images (1910-1915) are concerned with the masses who inhabit the modern city. Aldington is at pains to stress his distinction from those he perceives as an increasingly homogenized crowd. This paper examines the literary, linguistic and rhetorical strategies by which Aldington 'others' the masses, and sets them in the context of contemporary studies of the crowd, focusing on the work of Gustave Le Bon and C.F.G. Masterman. Aldington's poetry is a product of the environment he sees as unsatisfactory, but he searches for solutions in a range of literary traditions which write the city.

Keywords: city / crowd / Imagism / homogeneity / elitism

\section{Introduction: The Massed Crowd of Modernity}

The homogenizing force of the masses of men and women who inhabited the modern metropolis was a concern for high modernist authors. In his city poems in Images (19101915) Richard Aldington responds to and participates in the ongoing philosophical, sociological and intellectual debates about the role and values of the crowd. Commentators such as Gustave Le Bon and C.F.G. Masterman offered analyses of what they perceived as the pernicious effects of this crowd on civilization, and sought alternatives to conformity. Aldington draws on the same vocabulary to other the crowd, which is inarticulate, subdued and fragmented bodily, but feared for its unpredictability and power. He and other high 
modernist authors are apprehensive about the impact of mass culture on the literary marketplace. The reaction of representatives and proponents of elite culture against the masses borders at times on fascism, and in the cases of Ezra Pound, Wyndham Lewis and particularly Knut Hamsun led to their direct engagement with far-right politics. ${ }^{1}$ Aldington is politically engaged but does not do so. He seeks to make cultural impositions based on his understandings of classical civilizations and their cities, and believes passionately in the value of literature to effect change. He is placed within the city, but sees himself as the alien individual in a sea of conformity; paradoxically, he is not alone in this.

Richard Aldington was one of the original Imagist poets. He was at the (in)famous gathering at the British Museum teashop when Ezra Pound dubbed Hilda Doolittle, Pound's former fiancée and Aldington’s future wife, ‘H. D. Imagiste’. There are more poems by Aldington in the inaugural volume Des Imagistes (1914) than by any other author. His volume Images (1910-1915), on which I focus here, is from the moment Aldington's star burned brightest: he was an energetic and prominent figure in the London literary network. The poems in this volume chart his development from classicist verse in archaic diction to a poet of the city in modernity. Once Aldington went to war in 1916 it left an indelible mark on his life and verse. the Armistice was also in effect the death knell for his marriage to $\mathrm{H}$. D., and he would never again live for a substantial period in London. He produced less verse after the war, preoccupied in the 1920s by his work as a critic of French literature for

\footnotetext{
${ }^{1}$ On Pound's fascism see David Barnes, 'Fascist Aesthetics: Ezra Pound's Cultural Negotiations in 1930s Italy', Journal of Modern Literature 34, no. 1 (2010): 19 - 35; on Lewis see Vincent Sherry, Ezra Pound, Wyndham Lewis, and Radical Modernism (Oxford: Oxford University Press, 1993) and Andrew Hewitt, 'Wyndham Lewis: Fascism, Modernism, and the Politics of Homosexuality', ELH 60, no. 2 (1993): 527 544; on Hamsun see Peter Sjolyst-Jackson, Troubling Legacies: Migration, Modernism and Fascism in the Case of Knut Hamsun (London: Continuum, 2010) and Monika Zagar, Knut Hamsun: the Dark Side of Literary Brilliance (Seattle: University of Washington Press, 2009).
} 
the Times Literary Supplement, in the 1930s by his career as a novelist, and in later life by other projects, primarily biographical: he won the James Tait Black Memorial Prize in 1946 for his biography of Wellington, and his iconoclastic life of T. E. Lawrence (1955) provoked a backlash from his subject's supporters from which his reputation is yet to recover fully.

Like many of the Imagist poets, Aldington's poetry does not consistently fit with the oftquoted tenets of the group. That striving for directness, concision and variety of rhythm, however, is rarely consistently achieved. Andrew Thacker, following Mark Morrisson, sees the movement, and belonging to it or one similar, as a necessary promotional tool: 'Banding together via shared manifesto, group exhibition, and anthology or magazine publication bolstered promotion of one's own career.' ${ }^{2}$ When he came to write the Introduction to his Collected Poems (1948), Aldington suggested that it 'was a mere accident that what I was writing then chanced to meet with the approval of the verse revolutionaries', ${ }^{3}$ and disavowed any claim to novelty. This distancing is perhaps due to Pound's fascist actions in World War II and his subsequent incarceration as much as later reshaping of memories. While the rationale may not have been craven, the label enabled poets to be identified and identify with particular values, worked out in part on the fly as disparate Imagist groups coalesced and then diverged again. It was, in today's parlance, a 'brand' which proclaimed that the author sought to position him or herself amongst the most provocative, distinctive and challenging literary figures of the day. The poems of the second part of Images, which focus on the city, are some of Aldington's closest to the

\footnotetext{
${ }^{2}$ Andrew Thacker, The Imagist Poets (Tavistock: Northcote House / The British Council, 2011), 15.

${ }^{3}$ Richard Aldington, Introduction to The Complete Poems of Richard Aldington (London: Allan Wingate, 1948), 13.
} 
Imagist credos, and the fact that he separates these poems in the volume signifies a conscious shift in his own poetry. The presentation of London locales such as the 'Cinema Exit' and 'In the Tube' contrast with the Hellenic abstraction of early Imagist verse such as 'Choricos', the first poem in Des Imagistes, and 'To a Greek Marble'. His later poetry is long poetry after its fashionable post-war moment when Pound’s Hugh Selwyn Mauberley (1920) and, of course, T. S. Eliot's The Waste Land (1922) were much-discussed. In Aldington's poetry of 1914-15 we see a poet reaching maturity before the physical and emotional impact of the war took its toll, and discussing the key issues of modernist literature long before the annus mirabilis of 1922.

In early twentieth century accounts, two main terms are used largely interchangeably to describe the homogenized city dwellers: the crowd and the masses. Le Bon's The Crowd (1895) was an important early study, and Freud's 'Group Psychology and the Analysis of the Ego’ (1922) looked back to and valued Le Bon’s work highly. John Plotz describes the development of the term in the nineteenth century: 'both the fledgling radical demonstrations of the teens and Chartism's mammoth “simultaneous meetings” and petition processions of the 1840s came to be called “crowds” by those unwilling to grant them the status of demonstration, assembly, march, or congregation. ${ }^{4}$ Definition as a crowd denies legitimacy and seeks to categorise and diminish the potentially unruly group as a single entity. The term now usually signifies those watching live events which prize the physical and visceral; those attending classical concerts, theatre, or cultural pursuits which

\footnotetext{
${ }^{4}$ John Plotz, The Crowd: British Literature and Public Politics (Berkeley: University of California Press, 2000), 1-2. Plotz's focus is the literature of the first half of the nineteenth century; his concluding discussion of Charlotte Brontë's Shirley (1849) examines working-class reaction to mechanised modernity, in the form of the breaking of the machines. In this, and in other cases such as Elizabeth Gaskell's North and South (1855) the crowd is linked with class, both in going to the factory, and in revolt against capitalism.
} 
demand contemplation and reflection are usually an audience. In the sphere of mass culture, we speak of television 'audiences,' but those are contained within their own home, or policed in the studio. There is a qualitative difference in the term; the crowd is potentially more dangerous than the audience, but a level above the earlier "mob,” which term solely denotes disorder. The second term "the masses" starts to gain precedence in the early twentieth century, later highlighted in the title of José Ortega y Gasset's The Revolt of the Masses (1930; trans. 1932). Ortega and Julien Benda, whose The Betrayal of the Intellectuals (1927; trans. 1928) Aldington translated, look at the same dichotomy from apparently opposing angles in their titles, but both deal with the problems of mass living and mass culture. These philosophers sit outside the situation in contemplation, offering a theoretical analysis of the apparently inevitable calamity which will follow the empowering of the masses. Patrick Brantlinger has observed that 'very little has been written about mass culture, the masses, or the mass media that has not been colored by apocalyptic assumptions. ${ }^{5}$ The cultural elite's 'fears of invasion' are given voice from the earliest treatises on the mass as a phenomenon. Owen Jones has recently pointed out that it is a language which endures, ${ }^{6}$ while Jacques Rancière points out that 'The People are Not a Brutal and Ignorant Mass'. ${ }^{7}$

The serendipitous, even dangerous unpredictability of the crowd's reaction is a concern for opponents of mass culture: there is no guarantee of literary or political succession. The anonymity of the group removes accountability, strengthens its active power and offers

\footnotetext{
${ }^{5}$ Patrick Brantlinger, Bread and Circuses: Theories of Mass Culture as Social Decay (Ithaca, NY: Cornell University Press, 1983), 18.

${ }^{6}$ Owen Jones, Chavs: the Demonization of the Working Class (London: Verso, 2011), particularly 94.

7 Jacques Rancière, 'The People are Not a Brutal and Ignorant Mass', trans. David Fernbach, http://www.versobooks.com/blogs/1226-the-people-are-not-a-brutal-and-ignorant-mass-jacques-ranciere-onpopulism. Originally published in the French newspaper Libération on 3 January 2011.
} 
greater license for extreme actions. Le Bon claims that crowds may either degenerate into mob violence or unite in a common good cause: 'the crowd may, according to circumstances, be better or worse than the individual. All depends on the nature of the suggestion to which the crowd is exposed. ${ }^{, 8}$ Freud later posited more succinctly that 'a group impresses the individual as being an unlimited power and an insurmountable peril.' 9 The masses may accede to a conservative will, or rise in revolutionary response, depending on the personalities and principles involved; they may take up a number of options in a short space of time. ${ }^{10}$ The apparent serendipity on which this depends is a cause for concern for authors and authorities. Group action excludes intellectual elites almost by definition and, by implicit extension, nuanced readings of complex texts and situations. Le Bon's concern is that 'the divine right of the masses is about to replace the divine right of kings. ${ }^{11}$ Contemporary authors and commentators warn that not only will conformity be prized, but a mediocre, derivative rule will result.

The economic and the timely are over-emphasized by the crowd, removing any pretence to individuality. C.F.G. Masterman was a prominent commentator on social issues in the early years of the twentieth century, a Liberal MP following the landslide election of 1906, and linked to the modernist network via his friendship with Ford Madox Ford. Masterman notes that the condition of mass city living 'seems to tend to the elimination of the highest and lowest elements of human nature; the production of that nightmare vision of the speculative

\footnotetext{
${ }^{8}$ Gustave Le Bon, The Crowd, intro. by Robert A. Nye (New Brunswick, NJ: Transaction, 1995), 53.

${ }^{9}$ Sigmund Freud, 'Group Psychology and the Analysis of the Ego', in Beyond the Pleasure Principle, Group Psychology and Other Works, gen. ed. James Strachey. The Standard Edition of the Complete Psychological Works of Sigmund Freud (London: Hogarth, 1957), XVIII, 84-5.

${ }^{10}$ See Elias Canetti, Crowds and Power, trans. by Carol Stewart (Harmondsworth: Penguin, 1973$), 54$.

${ }^{11}$ Le Bon, 36.
} 
thinker, the Economic Man; weighed by the gross, estimated by the million.' ${ }^{12}$ The smallest conceivable number is over a hundred, the term 'gross' perhaps punning on the traditional term for twelve dozen to suggest the quality of the people described; so many are they that their number cannot be assessed accurately. The population of London had increased by over a hundred per cent in the fifty years before the First World War, and Masterman claimed that during the nineteenth century 'the population has multiplied itself sevenfold, and still shows no check to its impetuous increase. ${ }^{13}$ Elias Canetti, writing almost fifty years later, puts it pithily: 'The urge to grow is the first and supreme attribute of the crowd.' 14 The effects of this expansion within living memory are felt in vocabulary and rhetoric, as well as in living conditions. Masterman goes on to posit that people living in the suburbs 'form a homogeneous civilization,-- detached, self-centred, unostentatious,'15 and projects a vision which is seated uncomfortably between optimism and despair:

A race can thus be discerned in the future, small, wiry, incredibly nimble and agile in splicing thread or adjusting machinery, earning high wages in the factories, slowly advancing (one may justly hope) in intelligence and subtlety, and the qualities which go to make the good citizen. These may at the last limit their hours of labour everywhere to the ideal of an eight hours day; everywhere raise their renumeration to a satisfactory minimum wage; everywhere find provision for

\footnotetext{
${ }^{12}$ C.F.G. Masterman, From the Abyss: of its Inhabitants by One of Them (London: R. Brimley Johnson, 1902), 35.

${ }^{13}$ C.F.G. Masterman, 'The English City', in England: a Nation: Being the Papers of the Patriots' Club, ed. Lucian Oldershaw (London and Edinburgh: R. Brimley Johnson, 1904), 48.

14 Canetti, 17.

${ }^{15}$ Masterman, Condition of England, 69 - 70.
} 
insecurity, unemployment, old age. The 'Crowd' is then complete. The City civilisation is established. Progress pauses- exhausted, satisfied. Man is made. ${ }^{16}$

Optimism is undercut by the implication that the present-day mass man lacks intelligence and subtlety, and that the end of this project to naturalize mass life and living will see the end of progress. The masses are bound by their position in the economy, individual actions only supporting collective aims, while the state collectively supports them in their contribution to the economy. The external, elite view of mass culture as relentlessly conformist continues to be recalled verbally in the title of the Mass Observation project in the late 1930s, which suggests that the crowd should be observed, but not interacted with. The devaluing of the crowd itself parallels the reduced cost of the items it produces and desires. In Freud's view, 'the individual feels incomplete if he is alone, ${ }^{17}$ and this extends to culture and consumption; having the same things as one's peers becomes a badge of honour.

\section{The Crowd and Culture}

Aldington needed the crowd. He did not have the benefit of regular patronage in the early part of his career, and thus needed to sell books or articles. ${ }^{18}$ The main way to make sales was by appealing to the mass which he held in such contempt. There was an increasing reading public; John Carey suggests that 'the difference between the nineteenth-century

\footnotetext{
${ }^{16}$ Masterman, Condition of England, 133 - 34.

${ }^{17}$ Freud, 118.

${ }^{18}$ Caroline Zilboorg fictionalizes the early years of Aldington's career in Transgressions (Writing From Here, 2011). See chapters one and two.
} 
mob and the twentieth-century mass is literacy. ${ }^{19}$ This literacy is not encouraging for contemporary commentators in the UK or the US. F.R. Leavis proclaims that 'In any period it is upon a very small minority that the discerning appreciation of art and literature depends. ${ }^{20}$ The attempts of authors to stress their individuality are doomed to incomprehension, as the majority lack the ability to engage with anything other than mimetic culture. When H.L. Mencken writes that 'intelligence is precisely the thing that the great masses of the plain people are congenitally and eternally incapable of' he refers to specific forms of higher learning, creative and philosophical thought. ${ }^{21}$ José Ortega y Gasset posits that 'we are living in a levelling period,' showing a fear that increased ability to consume culture will adversely affect its quality. ${ }^{22}$ Brantlinger observes that " "the masses," it was often feared, would drag everything down to their level': not only down a level, but also to their level; not only lower while remaining variable, but also uniform. ${ }^{23}$ Aldington is keen to reject the outdated values of the previous generation - his parents' generation, the Victorians. Indeed, in his later memoir Life for Life's Sake (1941) his first chapter concludes: 'before the Queen's death and before Mafeking, an event happened of more importance to me. I went to live in the country. ${ }^{24}$ He emphasizes the break with the Victorians, and his move away from the city; he is acutely aware that, as Zygmunt Bauman puts it, 'the product of the first discourse was the notion of culture as the capacity to resist the norm and rise above the ordinary. ${ }^{25}$ However, texts and cultural forms which question established values are unlikely to reach the audience perceived as in greatest need of

\footnotetext{
19 John Carey, The Intellectuals and the Masses: Pride and Prejudice among the Literary Intelligentsia, 18801939 (London: Faber and Faber, 1992), 5.

${ }^{20}$ F.R. Leavis, Mass Civilisation and Minority Culture (Cambridge: The Minority Press, 1930), 3 - 4.

${ }^{21}$ H.L. Mencken, 'Education', in Prejudices: Third Series (New York: Knopf, 1922), 238.

22 José Ortega y Gasset, The Revolt of the Masses, trans. Brian Carey (New York: Norton, 1993), 26.

${ }^{23}$ Brantlinger, 32.

${ }^{24}$ Richard Aldington, Life for Life's Sake: A Book of Reminiscences (1941; London: Cassell, 1968$), 15$.

25 Zygmunt Bauman, Culture as Praxis, new edition (London: Sage, 1999), xvi.
} 
improvement. The largely conservative nature of the crowd also indicates a resistance to leaving behind entrenched social practices and values. ${ }^{26}$ Aldington's reaction against the crowd presupposes its inability or unwillingness to appreciate the same forms of culture as him. Sean Latham observes that:

Throughout both highbrow modernism and middlebrow fiction, we can glimpse a deep sense of ambivalence about the costs of aesthetic success- costs often measured in the fear of a mass audience and a simultaneous dissatisfaction with the isolation of a coterie readership. ${ }^{27}$

This ambivalence also attempts to justify the coterie readership of many high modernist authors. Aldington had to negotiate for himself a space between his belief in particular forms of aesthetic value, his need to survive by earning money from his writing, and a desire to create literature with social value.

\section{Moving Images}

These fears often found a focus in the rapidly-growing cinema industry. While James Joyce was famously an early proponent of the form, many modernist and avant-garde authors considered the film medium impermanent and aesthetically unsatisfactory: even before the advent of the talkies, visual and audio cues meant that, according to cultural commentators such as Leavis, the film required less interpretation and engagement from its audience, who

\footnotetext{
${ }^{26}$ On the British understanding of intellectuals see, for example, Stefan Collini, Absent Minds: Intellectuals in Britain (Oxford: Oxford University Press, 2006), particularly chapters three to five.

${ }^{27}$ Sean Latham, Am I a Snob?: Modernism and the Novel (Ithaca, NY: Cornell University Press, 2003), 2.
} 
became passive recipients without the capacity for imagination and analysis. ${ }^{28}$ The film is truly mass culture- accessible to a mass audience by virtue of a lower actual and metaphorical price of entry. In the pre-war years the average price of a cinema ticket was markedly less than the 7/6d for a single volume novel of average length, just a few pence, rather than several shillings. ${ }^{29}$ There is an active desire to expunge from the official record working-class culture. Masterman claims that as in the Middle Ages, the working class will not be remembered, asserting that this is 'a picture in which the waste and scattering and crushing out of the possibilities of life in the ordinary undistinguished multitude will, to the eyes of the future, thrust a black smudge across the background of the twentieth century., 30 He observes that the masses are victims of the culture of their times. In making this sympathetic assertion he belittles the multitude, and describes their absence as a 'black smudge'; ironically, even when visible the masses are described in terms of darkness and obscurity. Masterman suggests that the new elite to be feared are the technicians and, by extension, the bureaucrats- the agents of the mechanical culture of conformity and efficiency which has become prevalent. ${ }^{31}$

\footnotetext{
${ }^{28}$ Virginia Woolf puts forward this viewpoint in 'The Cinema', in The Nation and Athenaeum, 3 July 1926, $381-383$, in which she comments on the savagery of the medium, although offering suggestions for its development. In an even more extreme critique, F.R. Leavis and Denys Thompson claim in Culture and Environment: the Training of Critical Awareness (London: Chatto \& Windus, 1933) that films are a 'counterinfluence' to 'the possibilities of training taste and sensibility' (1). However, the literary response to films was not uniform. Indeed, authors such as H.D. and Iris Barry were in favour of the new medium. Barry argues that: 'Critics and connoisseurs demonstrate their deep sense by damning the films in every key. So those of us who go to the pictures every week, or every day, keep it rather quiet, or allude to it as being cheap, or restful. Others of us even allege that it solves our complexes.' Let's Go to the Pictures (London, Chatto \& Windus, 1926), viii. H.D. and Bryher notably experimented with avant-garde cinema in the nineteen twenties and thirties with their POOL Films collective, which produced the journal Close Up (1927 - 1933) and a number of films using the montage technique- only Borderline (1930) survives in full.

${ }^{29}$ Nicholas Hiley demonstrates that the majority of cinema tickets sold in 1916 cost between 3 and 6d, with even the most expensive tickets retailing at one shilling. See Hiley, 'The British Cinema Auditorium', in Film and the First World War, ed. Karel Dibbets and Bert Hogenkamp (Amsterdam: Amsterdam University Press, 1995), 162.

${ }^{30}$ Masterman, From the Abyss, 27.

${ }^{31}$ See Evelyn Cobley, Modernism and the Culture of Efficiency: Ideology and Fiction (Toronto: University of Toronto Press, 2009).
} 
Aldington did not comment extensively on the cinema in prose, although he later came to sympathise with producers for the censorship they endured, following the need to expurgate his war novel Death of a Hero (1929). ${ }^{32}$ However, in his early poetry he demonstrates the prejudices of the age and places the blame for artistic decline upon the masses for their failure to demand more from the culture they consume and their complicity in sustaining these processes of production. The masses are literally and metaphorically unenlightened, controlled by electric light, natural light, and darkness in the absence of both these.

Aldington criticises the medium of film and its audience in 'Cinema Exit':

After the click and whirr

Of the glimmering pictures,

The dry feeling in the eyes

As the sight follows the electric flickerings,

The banal sentimentality of the films,

The hushed concentration of the people,

The tinkling piano- ${ }^{33}$

The films are transient modern representations of life, 'electric flickerings' of 'glimmering pictures.' These impermanent irregular images are enough to control the gaze of the viewers, keeping them in 'hushed concentration,' and they hinder vision by causing a 'dry feeling in the eyes.' The banality of the films is echoed in lines four to six by a tetrameter which is more regular than the poem's free verse. Later in the stanza the description of the

\footnotetext{
${ }^{32}$ See Richard Aldington, 'Freedom of the Press', in Artifex (London: Chatto \& Windus, 1935), 103.

${ }^{33}$ Richard Aldington, 'Cinema Exit', in The Complete Poems of Richard Aldington (London: Allan Wingate, 1948), 48.
} 
film is transposed onto the viewers, who 'flicker in oblique rays of dark and light.' ${ }^{34}$ Not only are the films banally sentimental, but the people are too, unable to distinguish good art from bad.

Artificial light holds the crowd in place and reduces the possibility for disorder both inside and outside, although the effort at control is resisted. As the doors are thrown open, Aldington's cinema crowd is illuminated:

Suddenly,

A vast avalanche of greenish-yellow light

Pours over the threshold;

White globes darting vertical rays spot the sombre buildings;

The violent gloom of the night

Battles with the radiance;

Swift figures, legs, skirts, white cheeks, hats

Flicker in oblique rays of dark and light. ${ }^{35}$

The single dactyl 'suddenly' marks a volta in this long stanza, a turn from the moribund to a language of movement. This bile-coloured light is described in terms of natural disaster, and battles with 'the violent gloom of the night.' The only end-rhymes of the poem, 'night' and 'light', encase darkness between two instances of artificial light. The battle between darkness and electric light outside is a re-enactment of the 'electric flickerings' indoors.

\footnotetext{
${ }^{34}$ Aldington, 'Cinema Exit', 48.
}

${ }^{35}$ Aldington, 'Cinema Exit', 48. 
Darkness suggests disorder, culturally, visually and physically. Individuals cannot be identified, and only smooth blank pieces of skin are visible; clothing is without identifying colour or cut. The blandness of early films meant that public order was a serious official concern; the gripping suspense of narrative cinema was still to develop fully. ${ }^{36}$ 'In official circles,' Matt Houlbrook argues, ‘darkness was assumed to underpin the existence of sexual transgression.' ${ }^{37}$ Canetti posits that 'in the dark, the fear of an unexpected touch can mount to panic. ${ }^{38}$ That touch is neither necessarily unexpected nor unwelcome. Darkness has a cultural, moral, and religious valence. Many viewers were impressed by the exhibition of technological progress, and the low cost of entry made the cinema an ideal place to meet and mingle; Hiley states that 'in 1914 the British cinema auditorium was [. . . ] a proletarian public sphere.' ${ }^{39}$ The power of the cinema to fix some of its audience in their seats was clear, but additional light was needed to control movement once seated: 'From 1916 licensing provisions demanded "shaded lights along the side so audiences can see each other" and supervision by trained staff "each with an electric torch to frequently patrol the gangways, switching the light along the rows of seats to detect any improper acts." 40 The high modernists' aesthetic antipathy to the cinema was accompanied by practical antipathy in the form of legislation. Authors and authorities in all domains were concerned by the potential power of the masses if allowed the freedom to consume and behave as they wished.

\footnotetext{
${ }^{36}$ See, for example, Graham Turner, Film as Social Practice, third edition (London and New York: Routledge, 1999), 34-7.

${ }^{37}$ Matt Houlbrook, Queer London: Perils and Pleasures in the Sexual Metropolis (Chicago, IL: University of Chicago Press, 2005), 58.

${ }^{38}$ Canetti, 15.

${ }^{39}$ Hiley, 164.

${ }^{40}$ Houlbrook, 58.
} 
Aldington devalues the city crowd as he demonstrates the constriction and restriction it faces, a malady specific to the modern city:

\section{Millions of human vermin}

Swarm sweating

Along the night-arched cavernous roads. ${ }^{41}$

The crowd is vermin, and the pejorative description is given added emphasis by the new stanza; the falling dactylic / trochaic rhythm of its opening line indicates that these people are symptomatic of decline. Those who purchase, engage with and create mass culture are seen as subhuman, so small as to be indistinguishable. The swarm representing collective behavior and safety in numbers as an amorphous mass, and also evokes the unspecified end of the search for a new colony or habitat in nature. The crowd shares with vermin a doubleedged character; it can be harmful and destructive, or productive. At best, insects such as bees and ants work together as part of a natural machine. Masterman describes 'the huge piles of tenements [which] encompass the bewildered occupants in a kind of human antheap; there the ancient dwelling of the wealthy or comfortable classes have been "swarmed out” by the busy people. ${ }^{42}$ Buildings are constructed by city-dwellers secondary to existing conditions- they encompass, rather than being entered and occupied. The phrasing of both Aldington and Masterman recalls Baudelaire's 'Au Lecteur,' the preface to Les Fleurs $d u$ Mal, in which city crowd is 'close, swarming, like a million writhing worms. ${ }^{43}$ John Plotz

\footnotetext{
${ }^{41}$ Aldington, 'Cinema Exit', 48.

${ }^{42}$ Masterman, Condition of England, 98 - 9.

${ }^{43}$ Charles Baudelaire, 'Au Lecteur', in The Flowers of Evil, trans. James McGowan (Oxford: Oxford University Press, 1993), 5.
} 
observes that the word 'crowd' operates both as verb and as noun, ${ }^{44}$ as does 'swarm'. Both descriptions allude to the extreme filling of space and movement of the group, rather than the individual. For the crowd itself, according to Canetti, this is one of the fundamental qualities of its experience: 'The crowd loves density. It can never feel too dense. Nothing must stand between its parts or divide them; everything must be the crowd itself. ${ }^{45}$ The city roads which the patrons at the 'Cinema Exit' traverse are 'cavernous,' signifying darkness and enclosure, with only narrow apertures to exit. They are also 'night-arched,' and this apparent oxymoron contrasts the dark arch of the road's tarmacadam, which pushes detritus off to the gutters that run alongside the pavements populated by the crowd, with the opposite shape of the cavernous spaces between the high-sided city buildings. Masterman notes that 'the footpaths and roadways are choked with human life.' ${ }^{46}$ Created out of a need for space in which people can maneuver, the roads and paths are now impassable; the airways of the city are blocked.

The closing stanza of 'Cinema Exit' demonstrates Aldington's extreme antipathy toward mass culture. The language he uses has such animosity that it suggests fascism and eugenics. The conclusion is marked out typographically: the speaker states in parenthetical relief in a new stanza, like an aside to the reader, that '(Happily rapid chemical processes / Will disintegrate them all.), ${ }^{47}$ The first line of the stanza is primarily dactylic and the second trochaic, the falling rhythm signalling the disintegration in the second line, which ends with the emphasis on 'all,' seeking the obliteration of mass men and women, along

\footnotetext{
${ }^{44}$ Plotz, 6.

${ }^{45}$ Canetti, 32.

${ }^{46}$ Masterman, From the Abyss, 88.

${ }^{47}$ Aldington, 'Cinema Exit', 48.
} 
with their culture. Counterintuitively the poem 'In the Tube' precedes 'Cinema Exit' in Images. However, both poems close similarly. The ambiguous question which concludes 'In the Tube'- 'What right have you to live?'- highlights typographically the profundity of the rhetorical question which is the death of the poem, the killing of the gazed-upon subjects by their inability to respond articulately to the speaker. ${ }^{48}$ That setting apart casts doubt on the origin of the question, which could equally be the defensive response of the line of subjects to difference in the form of the poet. Rachel Bowlby describes the problem of 'decoding' other inhabitants of the city, as the unknown, uncanny interaction hinders engagement. ${ }^{49}$ Canetti posits that 'a question is a forcible intrusion' ${ }^{50}$ so separate have individuals become psychologically, even within the crowd, that questions cannot be verbalised to break down the divisions between people.

The combination of these conclusions of successive poems in the volume evokes for the post-Holocaust reader alarming images of genocide. This reading is anachronistic, but it is plausible to see the poem as a comment on the first German gas attack on 22 April 1915: the inhalation of Chlorine quickly starves the blood of oxygen. ${ }^{51}$ However, I argue that these references allude to recent scientific discoveries about the universe by Einstein, Eddington, and Jeans. No longer is the rhetoric of religious salvation appropriate; death needs to be seen in a different, primarily secular way, as an end for the mass population which created the city, caused by the vicissitudes of city living. The crowd seals its own fate. The disintegration caused by 'rapid chemical processes' also evokes film technologies,

\footnotetext{
${ }^{48}$ Aldington, 'In the Tube', in Complete Poems, 49.

${ }^{49}$ Rachel Bowlby, 'Readable City', in PMLA 122, no. 1 (2007), 307.

${ }^{50}$ Canetti, 331.

${ }^{51}$ Simon Jones, World War I Gas Warfare: Tactics and Equipment (Oxford: Osprey, 2007), 5-6.
} 
in this case the disintegration of continuous time into a snapshot, and the process of developing images from negatives. David Ayers posits that Aldington’s 1929 war novel Death of a Hero should be read as a 'proto-fascist novel', ${ }^{52}$ and the origins of that claim are apparent in these poems. However, there is little in Aldington's life or letters which suggests any development past the sentiments expressed in his early work. He had no flirtation with the public politics of fascism, and strongly criticised Pound for his Second World War broadcasts, which he said exhibited the 'sickening degradation of a human spirit. ${ }^{53}$ His politics were always liberal and permissive, and highlighted his belief in the Republic of Letters.

If it must be seen in such terms, Aldington's is a literary and cultural fascism; his belief in the educative and transformative power of literature accounts for his antipathy towards mass culture. This can hardly be fascism in the political sense: fascism relies on an unreflective mass appeal. While Aldington might be criticised as elitist, he cannot simultaneously be fascist. Roger Griffin argues that fascism should not just be seen 'as predisposed to accommodate forms of cultural and social modernism, but as constituting a form of political modernism in its own right. ${ }^{54}$ Aldington wrote later that 'art is a flowering of the life impulse,' and was aware of the paradox of that valuation of literature. ${ }^{55}$ If literature is to be improving, it needs to be read; to appeal to a wide audience removes the possibility of putting forward a distinctive, provocative message: 'If authors

\footnotetext{
52 See David Ayers, English Literature of the 1920s (Edinburgh: Edinburgh University Press, 1999), 19-29.

${ }^{53}$ Richard Aldington to Henry Slonimsky, 19 October 1941, in Richard Aldington: an Autobiography in Letters, ed. Norman Gates (University Park: University of Pennsylvania Press, 1992), 186.

${ }^{54}$ Roger Griffin, 'Modernity, modernism and fascism: a "mazeway resynthesis"', in Modernism / Modernity 15, no. 1 (2008), 17.

${ }^{55}$ Aldington, 'Freedom of the Press', 109.
} 
continue to measure success in terms of réclame (and what réclame!) and sales, then they doom themselves to contempt and incompetence.' ${ }^{56}$ Zygmunt Bauman argues that:

the call for the education of the masses was simultaneously a declaration of the masses’ own social incompetence and a bid for the dictatorship of the professoriat (or, to use the educated elite's own vocabulary, for the 'enlightened despotism' of the guardians of reason, humane manners and good taste). ${ }^{57}$

Aldington had contempt for what he perceived as the numbing effect of mass media. Where he and his peers believed that literature's aim should be improving, mass-market journals such as the Northcliffe papers actively pandered to the lowest common denominator. In looking back at his reporting of Imperial news Kennedy Jones, a senior Northcliffe man, recalled that: “"Don't forget you are writing for the meanest intelligence” was a favourite dictum of mine.' 58 The language used is similar to that employed by Aldington, Masterman and Le Bon, but rather than attempting to improve the lot of the city dweller, such figures and organisations exploit the market demand for digested news; Collier asserts that 'critics saw the emphasis on human interest as signifying a modern lack of proportion, a fascination with sensations and trivialities. ${ }^{59}$ The spread of the mass media ensures that Aldington and his peers are unlikely to achieve a wide audience. The tying of literary

\footnotetext{
${ }^{56}$ Richard Aldington, 'Ethics of Authorship', in Artifex, 183.

${ }^{57}$ Bauman, Culture as Praxis, xxxiii.

${ }^{58}$ Kennedy Jones, Fleet Street and Downing Street (London: Hutchinson, 1920), 145.

${ }^{59}$ Patrick Collier, Modernism on Fleet Street (Aldershot: Ashgate, 2006), 14. Implicit in this statement is a gendered reading of the problems of mass culture, and women's links with shopping and consumerism. See Rachel Bowlby, Just Looking: Consumer Culture in Dreiser, Gissing and Zola (London: Methuen, 1985), particularly chapter 2, 'Commerce and femininity', and also Bowlby, Carried Away: the Invention of Modern Shopping (London: Faber and Faber, 2000).
} 
production increasingly to the marketplace was seen as a threat to authorial liberty which, ironically, needs to be maintained by a form of cultural fascism.

\section{Crowds and Crowding}

Symbols of technological modernity both destabilise and contain those who come into contact with them. The tension between artificial light and natural darkness is heightened when it takes place on mechanised transport; the electrification of the tube- from its initial, frankly dangerous-sounding steam-powered incarnation- was ongoing in the early twentieth century. ${ }^{60}$ In Aldington's 'In the Tube' the train causes physical uncertainty and instability for the speaker, delaying his engagement with his surroundings:

The electric car jerks;

I stumble on the slats of the floor,

Fall into a leather seat

And look up. ${ }^{61}$

The train passes on its violent motion to the entering passenger, and the unpredictable regularity of that movement is echoed in the form of the first stanza, in which each line has three stresses, but the spaces between these vary from the staccato ('The eléctric cár jérks') to the legato ('I stúmble on the sláts of the flóor'). The gaze of the speaker is violently altered by the almost-imperative 'And look up,' but he sees only further images:

\footnotetext{
${ }^{60}$ Roy Porter, London: a Social History (London: Hamish Hamilton, 1994), 311-7.

${ }^{61}$ Aldington, 'In the Tube', 49.
} 
A row of advertisements,

A row of windows,

Set in brown woodwork pitted with brass nails,

A row of hard faces,

Immobile,

In the swaying train,

Rush across the flickering background of fluted dingy tunnel; ${ }^{62}$

Andrew Thacker observes that 'the appellation [Imagist] merely drew upon the "cult of images” pressing all around one in the spaces of modernisation. ${ }^{63}$ These images are not aesthetic but commercial, advertising mass-produced items to a mass consumer public- a practice which continues in the station, on the platform, and in the trains of the London Underground today. As in the cinema, the crowd is immobile as the images appear to move, a 'flickering background' which recalls the 'electric flickerings' of the cinema. Stillness here is a paradox, as the viewers of these images are being moved whilst themselves remaining stationary. Mechanical processes still create the illusion of the moving image, but neither the image itself nor the people are mobile. Even in the act of being transported back to the new suburbs, where the modern man dwells, he is fixed in the carriage. Moreover, the traveller is doubly fixed inside: his act of looking out of the carriage brings a view only of another dark interior, artificially lit to enable the viewing of artificial images, and occluding any sense of distance travelled. Aldington writes on the cusp of the shift from city crowd to suburban living, and himself commuted into London from his family

\footnotetext{
${ }^{62}$ Aldington, 'In the Tube', 49.

${ }^{63}$ Andrew Thacker, Moving Through Modernity: Space and Geography in Modernism (Manchester: Manchester University Press, 2003), 92.
} 
home in Teddington while in his short time at university, which ended due to his father's financial misfortunes. ${ }^{64}$ His suburbia is reinterpreted based on repeated experience combined with attempts to understand and interpret modernity. The general shift to suburbanism was partly facilitated by improvements in transport links such as the tube, which built out to then greenfield sites. ${ }^{65}$ Lynne Hapgood posits that:

London's margins continued to be redrawn as new communities colonised them, redesignating what was marginal as integral. Social commentators, so recently exercised by the struggle to define the horrors of inner city conditions, were faced with the task of defining the enigma of a new kind of landscape which seemed single-mindedly intent on evading definition. ${ }^{66}$

The enigmatic nature of this new model made it potentially more dangerous than the dark, homogenized city. It promised to allow freedom: freedom of movement in the larger plots of land allocated for suburban houses, and also the individual freedom generated by this space.

The bodies of the mass men and women are fragmented within the conformity of their surroundings. Their individuality comes from incapacity and inability; even this putative difference is based only on body parts and generic clothing. In 'In the Tube,' the items the

\footnotetext{
${ }^{64}$ See Richard Aldington and H.D.: Their Lives in Letters, 1918-61, ed. Caroline Zilboorg (Manchester: Manchester University Press, 2003), 4, and Charles Doyle, Richard Aldington: A Biography (Basingstoke: Macmillan, 1989), 9-12.

65 See, for example, Richard Hornsey, 'Listening to the Tube Map: rhythm and the historiography of urban map use', Environment and Planning D: Society and Space 30, no. 4 (2012), 685.

${ }^{66}$ Lynne Hapgood, Margins of Desire: the Suburbs in Fiction and Culture, 1880-1925 (Manchester:

Manchester University Press, 2005), 2-3.
} 
speaker observes are all in homogeneous rows: 'A row of advertisements, / A row of windows' become 'A row of hard faces,' then 'A row of eyes. ${ }^{67}$ As Thacker observes, 'the ordered structure of this 'row' [of advertisements] gets displaced onto other signifiers. ${ }^{68}$ The commercial and modern are displaced onto the human, again preventing bodies being seen whole and negating individual identity. The observer's gaze is drawn in from the whole visage to the 'Eyes of greed, of pitiful blankness, of plethoric complacency, / Immobile. ${ }^{69}$ Eyes usually offer an insight into character and mind, and here those insights are bleak. The eyes are avaricious within a blank expression, which suggests a lack of intellectual engagement and an unhealthy level of contented self-pleasure. Their physical characteristics highlight the lack of distinction: they are 'brasslike,' recalling the nails in the woodwork of the train described in the first stanza. ${ }^{70}$ The regular spacing of the nails and their round blank heads is echoed by the expressionless faces of the passengers, who are also indistinguishable; Aldington evokes the ethereal faces in Pound's 'In a Station of the Metro'. Here, however, the nails, like the people, serve a prosaic but useful function. The presumption of a lack of human emotion transforms the disparate individuals into a single, threatening presence. Thacker comments that 'this reifying gaze signals not only contempt towards the non-artist, but also the defensive strategy of an aesthetic group threatened by the "blankness" of these eyes. ${ }^{71}$ Somehow, these hard faces with blank expressions manage to show 'Antagonism, / Disgust, / Immediate antipathy. ${ }^{72}$ However, these negative

\footnotetext{
67 Aldington, 'In the Tube', 49.

68 Thacker, 94.

69 Aldington, 'In the Tube', 49.

70 Ibid.

71 Thacker, 93.

72 Aldington, 'In the Tube', 49. See also Aldington's friend and fellow Imagist F.S. Flint's similar poem 'Tube', in which he describes 'the mass, inert, / Unalarmed, undisturbed', and claims to 'look in vain for a sign, / For a light in their eyes. No!’ In Flint, Otherworld: Cadences (London: Poetry Bookshop, 1920), 36. David
} 
emotions might apply to the poem's speaker as much as the objects of his gaze. The voyeur's gaze is met and matched by those opposite to him, both in terms of their outlook and on the train. As Thacker pithily observes, 'Travelling by tube certainly dragged poets out of their sealed-up book closets. ${ }^{73}$

In other poems Aldington goes past the rhetoric of fragmentation and describes the city dwellers as deformed. Even the people we see working 'At the British Museum,' in a bastion of learning, have 'bent heads,' suggesting that intellectual advancement is accompanied by physical regression. ${ }^{74}$ This posture implies a pre-homo sapiens appearance, recalling the concerns of Max Nordau about the physical and mental character of the artist in Degeneration. For Aldington in Images, physical deformity is symptomatic of uniformity, not of distinction. In 'Church Walk, Kensington' he explicitly describes the subjects in terms of deformity: 'The cripples are going to church.' Physical imperfection is pervasive, and Aldington criticises the church attendees harshly:

Their clothes are black, their faces peaked and mean;

Their legs are withered

Like dried bean pods.

Their eyes are as stupid as frogs'. ${ }^{75}$

Ashford analyses these poems comparatively in 'Blueprints for Babylon: Modernist Mapping of the London Underground 1913 - 1939’, Modernism / Modernity 17, no. 4 (Nov 2010): 735 - 764, particularly 740 - 745.

73 Thacker, 88.

${ }^{74}$ Aldington, 'At the British Museum', 45. The Library at the British Museum and the associated reading room was a precursor to the modern-day British Library.

${ }^{75}$ Both quotations Aldington, 'Church Walk, Kensington', in Complete Poems, 47. 
The churchgoers are drab, dressed in black clothes. These garments have a dual resonance, of funeral mourning- as suggested by the subsequent poem 'St. Mary’s, Kensington’, which probes its impossibility- and of clerical costume. ${ }^{76}$ In either case, the figures are seeking a religious consolation in which the speaker does not believe. The withered legs show a population metaphorically crippled by what Aldington believes are outdated moral values and overly-restrictive social codes; adherence to these systems is linked directly with stupidity. Masterman describes 'the city Crowd, where the traits of individual distinction have become merged in the aggregate and the impression (from a distance) is of little white blobs of faces borne upon little black twisted or misshapen bodies. ${ }^{77}$ Aldington worries in these poems that the impact of city living will affect adversely the masses and the intellectuals who are forced to live in the same environment.

\section{Inarticulacy and Incomprehension}

The crowd's lack of ability to consume and appreciate high culture is often rendered as inarticulacy. The speeches and sounds made by the city dwellers in Aldington's city poems are indistinct, like the people making them. In ‘At the British Museum’ there are only 'rustling noises'-understandably in the library setting. ${ }^{78}$ The 'black murmuring crowd' of 'Hampstead Heath' is more sinister: the unidentifiable sound, both source and content, poses an apparent threat to the observer, who fears that which cannot be understood. Aldington draws on recent literary antecedents in his unvoicing of the crowd: Thomas

\footnotetext{
${ }^{76}$ Aldington, 'St. Mary’s, Kensington', in Complete Poems, 47.

${ }^{77}$ Masterman, Condition of England, 121.

${ }^{78}$ Aldington, ‘At the British Museum', 45.
} 
Carlyle described 'the distracted incoherent embodiment of Chartism' in $1840 ;{ }^{79}$ by the time Masterman reiterated this narrative in the early twentieth century it was less emphatically pejorative, but still distant from the experience of mass living: 'always noisy, we rarely speak; always resonant with the din of many-voiced existence, we never reach the language of ordered articulate utterance; never attain a language that the world beyond can hear. ${ }^{80}$ Barely a decade later, Masterman explicitly links the masses with inarticulacy: 'The multitude is the People of England: that eighty per cent. (say) of the present inhabitants of these islands who never express their own grievances, who rarely become articulate. ${ }^{81}$ He shows a paternalistic desire to express for them what he understands as their grievances and projects a desire and respect for authors and literature onto the objects of his scorn; he understands tacitly that the masses will become an important marketplace, as he describes 'the respect which the inarticulate Englishman instinctively feels for the voluble. ${ }^{82}$ No longer is it enough, Masterman suggests, simply for public authors to commentate on the news, a different sense of authority is now necessary: in the face of such inarticulacy authors need to become moral guides and gatekeepers for information.

Aldington highlights his own erudition, scholarship and individuality by invoking and then setting himself apart from traditions of writing about the city and modernity across languages and cultures. The only direct recounting of intelligible language in these poems is to indicate thought, or to quote from previous literary and cultural works. The quotation in 'At the British Museum'- 'I dream of silent verses where the rhyme / Glides noiseless as

\footnotetext{
79 Thomas Carlyle, 'Chartism', in The Victorian Age: an Anthology of Sources and Documents, ed. Josephine Guy (London: Routledge, 1998), 156.

${ }^{80}$ Masterman, From the Abyss, 20.

${ }^{81}$ Masterman, Condition of England, 96.

${ }^{82}$ Masterman, Condition of England, 126.
} 
an oar' - is perhaps a misquotation, or a quotation from memory of the Heimskringla, the Chronicle of the Kings of Norway. ${ }^{83}$ This reference evokes the position of the poet in literary history and in the chequered history of the nation- Hardrade was the Norse invader defeated at Stamford Bridge, shortly before the Norman Conquest at the Battle of Hastings in 1066. Aldington also situates himself in more recent literary history, quoting in 'Interlude' the final line from Baudelaire's preface to the Flowers of Evil, one of the urtexts for the interpretation of the modern city: 'Mon semblable, mon frère!' 84 The final lines are translated: 'Reader, you know this dainty monster too; / - Hypocrite reader, fellowman, - my twin!' 85 The sense of the French 'semblable,' rendered partly here in both ‘fellowman' and ‘twin,' has a wider meaning of alikeness and resemblance, and alludes to the conformity of the city dwellers while simultaneously pleading for an audience. Eliot uses the same line in The Waste Land to describe the sameness of the inhabitants of the 'Unreal City' at the end of 'The Burial of the Dead', further highlighting a high modernist need for engagement with key literary antecedents. ${ }^{86}$

\section{The Overpowering City}

Although the masses are inarticulate, the constant oppressive noise of the city makes thought and reflection impossible. 'Whitechapel' opens with the stressed single-syllable line 'Noise,' which exemplifies the condition of modern life. By the end of the first stanza that noise has become 'a vast mad cacophony'; the irrational nature of that sound and

\footnotetext{
${ }^{83}$ Aldington, 'At the British Museum', 45. In Samuel Laing's 1844 translation, the Saga of Harold Hardrade contains the lines "the far-known king the order gave, / In silence o'er the swelling wave, / With noiseless oars" (Sturlason II, 712).

${ }^{84}$ Aldington, 'Interlude', in Complete Poems, 50; Baudelaire, 6. Walter Benjamin begins 'On Some Motifs in Baudelaire', in Illuminations, trans. Harry Zorn (London: Pimlico, 1999), 152 - 190, with a discussion of the same phrase.

${ }^{85}$ Baudelaire, 7.

${ }^{86}$ T.S. Eliot, The Waste Land, in Collected Poems 1909 - 1962 (London: Faber and Faber, 1974), 65.
} 
assorted actions is again stressed, along with its all-encompassing nature. ${ }^{87}$ Adrian Gregory posits that:

Silence was something that many of the inhabitants of urban Britain may barely have known. By the early twentieth century there existed the continuous background noise of a modern society; the constant sound of people talking and moving in densely populated areas and the sounds of traffic, motorised and horsedrawn, would have been ever present, varying only in intensity. ${ }^{88}$

Traffic noise is manifested in the yard which houses Aldington's 'Eros and Psyche', which 'echoes with the rattle of cars and 'buses' transporting the masses to work, alongside 'freight trains, puffing steam and smoke and dirt / To the steaming sooty sky.' ${ }^{89}$ The background noise is often the waste product of industrial processes, the 'Iron beating upon iron' in 'Whitechapel' further emphasized by the stresses in the first stanza, which are nearly twice as many as unstressed syllables. This reaches its climax in the final stanza, which states the elements to which industrial society boils down in six emphatic singlesyllable words: 'Noise, iron, smoke; / Iron, iron, iron.’ The bigger picture of the first line, which evokes the factory setting, becomes merely the product itself. There is no longer any sense of the surrounding environment or any variation, just an instrumentalist vision of the iron, and each repetition of the word echoes the rhythm of the forge. The repetition of iron ten times in this short poem highlights the predominance of the labouring class in Britain's heavy industry and manufacturing: mining for iron ore and its consequent use formed a

\footnotetext{
${ }^{87}$ Aldington, 'Whitechapel', in Complete Poems, 62.

${ }^{88}$ Adrian Gregory, The Silence of Memory: Armistice Day 1919-1946 (Oxford: Berg, 1994), 13.

${ }^{89}$ Aldington, 'Eros and Psyche', in Complete Poems, 52.
} 
large part of manufacturing industry in the UK at the time and until the mid-1980s. Even when noise is humanised, as in 'Church Walk, Kensington,' it is a noise made by 'crutches beat[ing] upon the stones. ${ }^{90}$ Not only does the repetitive hammering echo the sound of the industrial forge, but the city's industry makes its inhabitants deteriorate physically as well as mentally.

In 'Whitechapel' the pastoral is engulfed by the necessities of labour and mass production. Whitechapel was famed for its deprivation, immortalised in Jack London's The People of the Abyss, in which he 'went down into the underworld of London [. . . ] and found that the starvation and lack of shelter encountered constituted a chronic condition of misery which is never wiped out, even in the persons of greatest prosperity.' ${ }^{91}$ The area is still remembered as the location for some of the Jack the Ripper murders. Robert Peluso comments, in discussing London's study of the slums, that 'the East End of London emerged during the 1880s and 1890s as a key location for British writers who wanted to construct or "prove” either flaws in industrial capitalism or problems with democratic politics. ${ }^{92}$ Of the poem's five stanzas, the odd-numbered describe city life, and hold in place those which are nostalgic for rural life. The conflict between country and city is enacted typographically and formally. The city stanzas are printed in Roman type, denoting mass-produced material. They hold in place the country stanzas, which are set in the cursive italic type which was created to mimic handwriting; ironically, that mimicry is performed for the processes of mass production. Those stanzas are also more formally

\footnotetext{
90 Aldington, 'Church Walk, Kensington', 47.

91 Jack London, People of the Abyss (New York: Grosset \& Dunlap, 1903), vii.

92 Robert Peluso, 'Gazing at Royalty: Jack London's The People of the Abyss and the Emergence of American Imperialism', in Rereading Jack London, ed. Leonard Cassuto and Jeanne Campbell Reesman (Stanford, CA: Stanford University Press, 1996), 56.
} 
regular, primarily in iambic trimeter, with the anaphoric repetition of 'In vain' highlighting the inability of the pastoral to endure. Each is cut off by a single stressed syllable; as the first lines of the city stanzas lengthen, the country stanzas decrease from five to four lines each. Spring's rebirth in the form of 'meadows Apriline' cannot provide an enduring alternative to the city's free verse and its insistent stresses, formally unruly yet conforming to the manifestoes produced by Pound, Flint and others. The drain on traditional forms of English country life, mourned over a hundred and fifty years previously in Gray's Elegy, has reached a point where, Masterman posits, 'no one today would seek in the ruined villages and dwindling population of the countryside the spirit of an "England" four-fifths of whose people have now crowded into the cities. ${ }^{93}$ This is a representational move, as well as a geographical one- England is no longer best represented by Romantic nature and sparse open countryside, but by the bustling modern metropolis.

Aldington's dislike for the masses is only in the loosest sense a political one. His criticisms in these poems derive from his concern about the impact of homogenization on the Republic of Letters, and on culture more generally. Culture can only exist in relation to its audience- much as Aldington wishes that were not so- and thus an increasingly similar audience can only lead to increasingly similar cultural products. One of the key values for modernist poetry is in distinction; the notion of standardized culture is abhorrent to Aldington, and to his modernist peers. Their demand for novelty does not attempt a wholly new poetry of the zeitgeist, but asks for knowledge of previous literatures and cultures. The debate for Aldington, H.D., and the writers with whom they are most closely associated, is which previous cultures provide the best language with which to describe the modern world,

\footnotetext{
${ }^{93}$ Masterman, Condition of England, 12.
} 
occluding any direct engagement with the mass culture of the early twentieth century. Similarly, Daniel Pick posits that 'in certain respects the language of degeneration, delineating classes and groups, circumscribed much of the argument in the very commissions and enquiries in the late-Victorian and Edwardian period which were set up to investigate and rules upon, precisely, the value of such concepts. ${ }^{94}$ Cultural literacy remains to the fore in the language Aldington uses to criticise the modern mass man, as he uses metaphors of light and dark, articulacy, and keeps in mind standardization of formsbodily, or poetic. His focus on culture above technology is highlighted by his recourse to the cultural forms of pre-modern civilizations, and of nations with a more progressive, liberal politics. In these poems, Aldington's poetry is produced by the city environment which he so decries. It gives him his subject, but his take on modernity is one based on reform or even revolution of the system. It is clear in these poems that Aldington is a poet of modernity, one of its most lucid and culturally-aware commentators; his work is dynamically engaged with the major concerns of his time, and he searches for solutions in literature to the apparent problems of life in the modern city, struggling to reconcile the conformity required by metropolitan living with his desire to uphold individuality and distinction in poetry and to use classical forms to represent modern life.

\footnotetext{
${ }^{94}$ Daniel Pick, Faces of Degeneration: a European Disorder, c. 1848 - c. 1918 (Cambridge: Cambridge University Press, 1989), 186.
} 


\section{Works Cited}

Aldington, Richard. Artifex. London: Chatto \& Windus, 1935.

---. The Complete Poems of Richard Aldington. London: Allan Wingate, 1948.

---. Life for Life's Sake: A Book of Reminiscences. 1941. London: Cassell, 1968.

---. Richard Aldington: an Autobiography in Letters. Edited by Norman T. Gates.

University Park: Pennsylvania State University Press, 1992.

---. Richard Aldington and H.D.: Their Lives in Letters, 1918-61. Edited by Caroline Zilboorg. Manchester: Manchester University Press, 2003.

Ashford, David. 'Blueprints for Babylon: Modernist Mapping of the London Underground 1913-1939.’ In Modernism / Modernity 17, no. 4 (Nov 2010): 735-64.

Ayers, David. English Literature of the 1920s. Edinburgh: Edinburgh University Press, 1999.

Barnes, David. 'Fascist Aesthetics: Ezra Pound's Cultural Negotiations in 1930s Italy.' In Journal of Modern Literature 34, no. 1 (2010): 19-35.

Barry, Iris. Let's Go to the Pictures. London: Chatto \& Windus, 1926.

Baudelaire, Charles. The Flowers of Evil. Translated by James McGowan. Oxford: Oxford University Press, 1993.

Bauman, Zygmunt. Culture as Praxis. New edition. London: Sage, 1999.

Benda, Julien. The Betrayal of the Intellectuals. Introduced by Herbert Read, translated by Richard Aldington. Boston, Mass.: Beacon, 1955.

Benjamin, Walter. 'On Some Motifs in Baudelaire.' In Illuminations. Translated by Harry Zorn. 152-190. London: Pimlico, 1999.

Bowlby, Rachel. Carried Away: the Invention of Modern Shopping. London: Faber and Faber, 2000.

---. Just Looking: Consumer Culture in Dreiser, Gissing and Zola. London: Methuen, 1985.

---. 'Readable City.' In PMLA 122, no. 1 (2007): 306-309.

Brantlinger, Patrick. Bread and Circuses: Theories of Mass Culture as Social Decay. Ithaca, NY: Cornell University Press, 1983.

Canetti, Elias. Crowds and Power. Translated by Carol Stewart. Harmondsworth: Penguin, 1973.

Carey, John. The Intellectuals and the Masses: Pride and Prejudice among the Literary Intelligentsia, 1880-1939. London: Faber and Faber, 1992.

Carlyle, Thomas. 'Chartism.' In The Victorian Age: an Anthology of Sources and Documents, edited by Josephine Guy, 155 - 66. London and New York: Routledge, 1998.

Cobley, Evelyn. Modernism and the Culture of Efficiency: Ideology and Fiction. Toronto: University of Toronto Press, 2009.

Collier, Patrick. Modernism on Fleet Street. Aldershot: Ashgate, 2006.

Collini, Stefan. Absent Minds: Intellectuals in Britain. Oxford: Oxford University Press, 2006.

Doyle, Charles. Richard Aldington: a Biography. Basingstoke: Macmillan, 1989.

Eliot, T.S. The Waste Land. In Collected Poems 1909-1962. London: Faber and Faber, 1974.

Flint, F.S. Otherworld: Cadences. London: Poetry Bookshop, 1920.

Freud, Sigmund. 'Group Psychology and the Analysis of the Ego.' In Beyond the Pleasure Principle, Group Psychology and Other Works, The Standard Edition of the 
Complete Psychological Works of Sigmund Freud. Translated from the German under the General Editorship of James Strachey. XVIII, 65-144. London: Hogarth, 1957.

Gregory, Adrian. The Silence of Memory: Armistice Day 1919 - 1946. Oxford: Berg, 1994.

Griffin, Roger. 'Modernity, modernism and fascism: a "mazeway resynthesis".' In Modernism / Modernity 15, no. 1 (2008): 9-24.

Hapgood, Lynne. Margins of Desire: the Suburbs in Fiction and Culture, 1880-1925. Manchester: Manchester University Press, 2005.

Hewitt, Andrew. 'Wyndham Lewis: Fascism, Modernism, and the Politics of Homosexuality.' In ELH 60, no. 2 (1993): 527-44.

Hiley, Nicholas. 'The British Cinema Auditorium.' In Film and the First World War, edited by Karel Dibbets and Bert Hogenkamp, 160-70. Amsterdam: Amsterdam University Press, 1993.

Hornsey, Richard. 'Listening to the Tube Map: rhythm and the historiography of urban map use’, Environment and Planning D: Society and Space 30, no. 4 (2012): 675-93.

Houlbrook, Matt. Queer London: Perils and Pleasures in the Sexual Metropolis. Chicago, IL: University of Chicago Press, 2005.

Jones, Kennedy. Fleet Street and Downing Street. London: Hutchinson, 1920.

Jones, Owen. Chavs: the Demonization of the Working Class. London: Verso, 2011.

Jones, Simon. World War I Gas Warfare: Tactics and Equipment. Oxford: Osprey, 2007.

Latham, Sean. Am I a Snob?: Modernism and the Novel. Ithaca, NY: Cornell University Press, 2003.

Le Bon, Gustave. The Crowd. Intro. by Robert A. Nye. New Brunswick, NJ: Transaction, 1995.

Leavis, F.R. Mass Civilisation and Minority Culture. Cambridge: The Minority Press, 1930.

Leavis, F.R., and Denys Thompson. Culture and Environment: the Training of Critical Awareness. London: Chatto \& Windus, 1933.

London, Jack. People of the Abyss. New York: Grosset \& Dunlap, 1903.

Masterman, C.F.G. The Condition of England. London: Methuen, 1909.

---. 'The English City.' In England: a Nation: Being the Papers of the Patriots' Club, edited by Lucian Oldershaw, 44-94. London and Edinburgh: R. Brimley Johnson, 1904.

---. From the Abyss: of its Inhabitants by One of Them. London: R. Brimley Johnson, 1902.

Mencken, H.L. 'Education', in Prejudices: Third Series, 238-65. New York: Knopf, 1922.

Ortega y Gasset, José. The Revolt of the Masses. Translated by Brian Carey. New York: Norton, 1993.

Peluso, Robert. 'Gazing at Royalty: Jack London's The People of the Abyss and the Emergence of American Imperialism.' In Rereading Jack London, edited by Leonard Cassuto and Jeanne Campbell Reesman, 55-74. Stanford, CA: Stanford University Press, 1996.

Pick, Daniel. Faces of Degeneration: a European Disorder, c. 1848-c. 1918. Cambridge: Cambridge University Press, 1989.

Plotz, John. The Crowd: British Literature and Public Politics. Berkeley: University of California Press, 2000.

Porter, Roy. London: a Social History. London: Hamish Hamilton, 1994.

Sherry, Vincent. Ezra Pound, Wyndham Lewis, and Radical Modernism. Oxford: Oxford University Press, 1993. 
Sjolyst-Jackson, Peter. Troubling Legacies: Migration, Modernism and Fascism in the Case of Knut Hamsun. London: Continuum, 2010.

Sturlason, Snorre. The Heimskringla: a History of the Norse Kings. Translated by Samuel Laing, revised by Magnus B. Anderson. 3 volumes. London: Norrœna Society, 1907.

Thacker, Andrew. Moving Through Modernity: Space and Geography in Modernism. Manchester: Manchester University Press, 2003.

---. The Imagist Poets. Writers and Their Work. Tavistock: Northcote House / The British Council, 2011.

Turner, Graham. Film as Social Practice. Third edition. London and New York: Routledge, 1999.

Woolf, Virginia. 'The Cinema.' In The Nation and Athenaeum, 3 July 1926. 381-3.

Zagar, Monika. Knut Hamsun: the Dark Side of Literary Brilliance. Seattle: University of Washington Press, 2009.

Zilboorg, Caroline. Transgressions. Writing From Here, 2011. 